\title{
STUDI DESKRIPTIF TINGKAT PENGETAHUAN IBU MENYUSUI TENTANG ASI EKSKLUSIF DI PUSKESMAS CILACAP UTARA
}

\author{
Lelia Kusuma Astuti \\ Fakultas Kesehatan Masyarakat, Universitas Ahmad Dahlan, Yogyakarta
}

\begin{abstract}
Background: Breastfeeding in Indonesia has not fully implemented. Efforts to increase breastfeeding behavior in women who have exclusively breastfed infants in particular is still considered insufficient. The main problem is the socio-cultural factors, awareness of the importance of breastfeeding, health services and health workers who have not fully support the PP-ASI, vigorous promotion of formula milk and the mother worked. Knowledge mother became one of the factors that influence exclusive breastfeeding. Phenomenon that occurs in the region of Central Cilacap district, was found in mothers who have not given exclusively breastfed their babies and mothers still do not know the benefits of exclusive breastfeeding.

Method: This was rurvey research using descriptive method. Data collection was spread out questionnaires, then the data obtained are processed statistically by descriptive analysis and presented in tabular form the frequency distribution. The number of respondents as many as 80 people.

Result: The results showed that respondents who had a level of knowledge of both exclusive breastfeeding as much as $78 \%$, the level of knowledge was $19 \%$, and who have less knowledge level of $3 \%$. White exclusive breasfeeding in the health center of Central Cilacap $60 \%$ and $40 \%$ of respondents did not give their babies breast milk exclusively.

Conclusion: Women who have knowledge of both exclusive breastfeeding is not always given exclusively breasfed their babies, because there are many other factors that influence exclucive breasfeeding.
\end{abstract}

Keywords : The knowledge of exclusive breastfeeding, exclusive breastfeeding.

\section{PENDAHULUAN}

ASI eksklusif menurut World Health Organization (WHO) adalah pemberian ASI saja (tanpa tambahan cairan lain, seperti susu formula, jeruk, madu, air teh, air putih, maupun makanan lain, seperti pisang, bubur susu, biskuit, bubur nasi, nasi tim, dan lain-lain), hingga bayi berusia 6 bulan. ${ }^{1}$ Konvensi Hak-hak Anak tahun 1990 antara lain menegaskan bahwa tumbuh kembang secara optimal merupakan salah satu hak anak. ASI selain merupakan suatu kebutuhan juga menjadi hak azasi bayi yang yang harus dipenuhi oleh orang tuanya. Hal ini telah dipopulerkan pada Pekan ASI sedunia tahun 2000 dengan Tema : "Memberi ASI adalah hak azasi ibu; Mendapat ASI adalah hak azasi bayi". ${ }^{2}$

Studi pendahuluan yang dilakukan sebelumnya di wilayah Kecamatan Cilacap Tengah dalam satu tahun terakhir terdapat 982 ibu yang melahirkan dan 951 ibu yang menyusui bayinya. Di perkotaan, banyak dijumpai bayi diberi susu botol daripada disusui oleh ibunya. Sementara di pedesaan, bayi yang baru berusia 1 bulan sudah diberi pisang atau nasi yang dihaluskan sebagai tambahan ASI. Selain itu, masih ditemukan beberapa ibu yang kurang mendapat informasi bahkan seringkali menerima informasi yang salah tentang ASI eksklusif. Ada anggapan bahwa kolostrum adalah susu basi yang harus dibuang dan bayi harus diberi makanan tambahan lain selain ASI untuk mempercepat pertumbuhannya.

Berdasarkan fenomena di atas dan penelitian mengenai pengetahuan tentang pemberian ASI eksklusif belum pernah dilakukan, maka peneliti tertarik untuk melakukan studi deskriptif tingkat pengetahuan ibu menyusui tentang ASI eksklusif di 
Puskesmas Cilacap Tengah. Penelitian ini bertujuan untuk mengetahui gambaran tingkat pengetahuan ibu menyusui tentang ASI eksklusif dan gambaran pemberian ASI eksklusif di wilayah Puskesmas Cilacap Tengah.

\section{METODE PENELITIAN}

Jenis penelitian yang digunakan adalah penelitian survey dengan metode deskriptif yaitu ditujukan untuk mengetahui gambaran tingkat pengetahuan ibu menyusui tentang ASI eksklusif dan gambaran pemberian ASI eksklusif oleh ibu kepada bayinya. Populasi dalam penelitian ini adalah semua ibu menyusui di wilayah Kecamatan Cilacap Tengah. Teknik pengambilan sampel pada penelitian ini adalah dengan cara total sampling. Sampel yang diambil untuk penelitian adalah populasi yang memenuhi kriteria inklusi. Adapun kriteria inklusi penelitian ini adalah sebagai berikut: a) Bersedia menjadi responden; b) lbu menyusui yang berkunjung ke Puskesmas Cilacap Tengah selama bulan Juni 2004; c) Mempunyai anak usia 6-24 bulan. Kriteria eksklusi penelitian ini adalah sebagai berikut : a) Tidak bersedia menjadi responden; b) Ibu menyusui yang memiliki anak di bawah usia 6 bulan. Analisis data dalam penelitian ini menggunakan analisis univariat yang digunakan untuk mendapatkan gambaran distribusi frekuensi serta untuk mendiskripsikan masingmasing variabel.

\section{HASIL PENELITIAN DAN PEMBAHASAN}

\section{A. Hasil Penelitian}

1) Karakteristik Responden

Tabel 1. Distribusi Frekuensi Karakteristik Responden di Puskesmas Cilacap Tengah

\begin{tabular}{lcc}
\hline \multicolumn{1}{c}{ Umur Responden } & Jumlah & Prosentase (\%) \\
\hline 1. Umur Responden & 2 & 3 \\
Kurang dari 20 tahun & 52 & 65 \\
$20-30$ tahun & 26 & 32 \\
Di atas 30 tahun & & \\
2. Pendidikan Responden : & 23 & 29 \\
SD atau sederajat & 21 & 26 \\
SLTP atau sederajat & 31 & 39 \\
SLTA atau sederajat & 5 & 6 \\
Perguruan Tinggi & & \\
3. Jenis Pekerjaan Responden : & 69 & 1 \\
Ibu rumah tangga & 1 & 8 \\
PNS & 6 & 5 \\
Swasta & 4 & \\
Wiraswasta & & 70 \\
4enghasilan Keluarga : & 56 & 21 \\
Kurang dari Rp 500.000,00 & 17 & 9 \\
Rp 500.000,00 - Rp 1.000.000,00 & 7 & \\
Di atas Rp 1.000.000,00 & &
\end{tabular}

Berdasarkan Tabel 1. diketahui mayoritas responden berusia 20-30 tahun yaitu sebesar $65 \%$ dan yang paling sedikit berusia kurang dari 20 tahun sebesar $3 \%$. Tabel 1. juga menunjukkan bahwa pendidikan responden yang paling banyak adalah 
pendidikan menengah (SLTP dan SLTA atau sederajat) yaitu 65\% dan yang paling sedikit adalah Perguruan Tinggi yaitu 6\%. Sebagian besar responden tidak bekerja atau sebagai ibu rumah tangga yaitu sebanyak $86 \%$, sedangkan $14 \%$ responden bekerja dengan variasi jenis pekerjaan sebagai PNS, swasta dan wiraswasta. Jika dilihat dari tingkat penghasilan paling banyak berpenghasilan kurang dari Rp. 500.000 sebesar $70 \%$.

\section{2) Analisis Univariat}

a) Tingkat Pengetahuan Ibu Menyusui tentang ASI Eksklusif

Tabel 2. Distribusi Frekuensi Tingkat Pengetahuan Ibu Menyusui tentang ASI Eksklusif Di Puskesmas Cilacap Tengah

\begin{tabular}{ccc}
\hline Tingkat Pengetahuan & Jumlah & Prosentase (\%) \\
\hline Kurang & 2 & 3 \\
Sedang & 15 & 19 \\
Baik & 63 & 78 \\
\hline Jumlah & 80 & 100 \\
\hline
\end{tabular}

Tabel 2. menunjukkan pada tingkat pengetahuan ibu menyusui tentang ASI eksklusif didapatkan sebagian besar responden mempunyai pengetahuan baik yaitu sebanyak 63 orang (78\%), responden yang mempunyai pengetahuan sedang sebanyak 15 orang $(19 \%)$, dan responden yang mempunyai pengetahuan kurang sebanyak 2 orang (3\%).

b) Pemberian ASI Eksklusif

Tabel 3. Distribusi Frekuensi Pemberian ASI Eksklusif di Puskesmas Cilacap Tengah

\begin{tabular}{ccc}
\hline Pemberian ASI Eksklusif & Jumlah & Prosentase (\%) \\
\hline Ya & 48 & 60 \\
Tidak & 32 & 40 \\
\hline Jumlah & 80 & 100 \\
\hline
\end{tabular}

Tabel 3. menunjukkan bahwa dari 80 responden hanya 48 orang $(60 \%)$ yang memberikan ASI eksklusif kepada bayinya dan 32 orang (40\%) tidak memberikan ASI eksklusif kepada bayinya.

\section{B. Pembahasan}

Berdasarkan hasil analisis data primer, dapat dinyatakan hasil penelitian yang menyangkut pengetahuan ibu menyusui tentang ASI eksklusif menunjukkan bahwa $78 \%$ dari responden mempunyai pengetahuan tentang ASI eksklusif baik. Data yang diperoleh menggambarkan bahwa sebagian besar responden berpendidikan SLTA yaitu $39 \%$. Bila dilihat dari jumlah responden yang berpendidikan Perguruan Tinggi, sebanyak $100 \%$ dari responden tersebut mempunyai tingkat pengetahuan tentang ASI eksklusif baik. Hal ini sesuai dengan pendapat Soekanto pada tahun 1987 yang dikutip oleh Sarif Hidayat bahwa tingkat pendidikan formal merupakan faktor yang ikut menentukan mudah tidaknya ibu menyerap dan memahami informasi gizi yang 
diperoleh. Semakin tinggi tingkat pendidikan formal ibu, semakin mudah ia menyerap informasi gizi dan kesehatan, sehingga pengetahuan dan kesehatannya akan baik. ${ }^{3}$ Hal ini memperlihatkan bahwa semakin tinggi tingkat pendidikan seseorang maka akan mempengaruhi pengetahuannya, seperti teori Green (1980) yang mengatakan bahwa pendidikan seseorang akan mempengaruhi tingkat pengetahuan seseorang. ${ }^{4}$ Jika dilihat dari jumlah responden yang berpendidikan SD atau sederajat hanya $8 \%$ yang memiliki pengetahuan tentang ASI eksklusif kurang dan 52\% memiliki pengetahuan tentang ASI eksklusif baik. Data tersebut menggambarkan bahwa ibu yang mempunyai pendidikan rendah belum tentu mempunyai pengetahuan tentang ASI eksklusif kurang. Menurut Notoatmojo, pengetahuan merupakan hasil 'tahu', dan ini terjadi setelah seseorang melakukan pengidraan terhadap suatu obyek tertentu. Sebagian besar pengetahuan manusia diperoleh melalui mata dan telinga. ${ }^{5} \mathrm{Hal}$ ini berarti dapat dikatakan juga bahwa pengetahuan seseorang tidak selalu didapat dari pendidikan formal tetapi juga dari pengalaman maupun informasi dari orang lain.

OPada item pertanyaan yang mengukur pengatahuan ibu menyusui tentang ASI eksklusif sebagian besar responden (79\%) memahami pengertian ASI eksklusif dan $75 \%$ responden memahami manfaat ASI eksklusif. Hasil penelitian ini menunjukkan angka yang lebih baik dibandingkan hasil dari penelitian terhadap 900 ibu disekitar Jabotabek pada tahun 1995 yang diperoleh fakta bahwa 70,4\% ibu tidak pernah mendengar informasi tentang ASI eksklusif. ${ }^{6}$ Perbedaan angka dari penelitian tersebut menggambarkan adanya peningkatan informasi tentang ASI eksklusif. Hal ini dikarenakan seiring dengan perkembangan zaman, terjadi pula peningkatan ilmu pengetahuan. Tetapi hasil penelitian juga menunjukkan bahwa sebanyak $25 \%$ responden belum memahami pengertian kolustrum, dan masih ada $10 \%$ responden yang berpendapat bahwa kolustrum tidak dapat diberikan kepada bayi. Hasil penelitian ini sedikit lebih baik dibandingkan hasil penelitian yang dilakukan di Kabupaten Barru, Sulawesi Tengah pada tahun 1997 yang menunjukkan sebanyak $17 \%$ ibu membuang kolustrum. ${ }^{2}$ Perilaku menyusui yang kurang mendukung seperti membuang kolustrum ini disebabkan masih adanya kepercayaan atau mitos bahwa ASI yang keluar pertama kali adalah susu basi, rusak, dan kotor sehingga pada harihari pertama para ibu tidak memberikan ASI pada bayinya. Fenomena ini selaras dengan pendapat Indrawijaya yaitu bahwa mereka yang berasal dari tingkat pendidikan rendah cenderung mempertahankan tradisi yang sudah ada. ${ }^{7}$ Adanya anggapan bahwa kolustrum adalah susu basi yang harus dibuang perlu dihilangkan dengan memberikan pengertian dan pemahaman kepada ibu-ibu tentang manfaat zat -zat yang terkandung dalam kolustrum bagi bayi yang baru lahir. Kolustrum, atau biasa disebut susu jolong, sudah terbukti mengandung berbagai zat gizi yang dibutuhkan oleh bayi sejak lahir. ${ }^{1}$

Pemberian ASI eksklusif ditentukan jika ibu hanya memberikan ASI saja kepada bayinya tanpa makanan tambahan sampai bayi berumur 4-6 bulan. Pada penelitian ini, peneliti menetapkan pemberian ASI eksklusif oleh ibu kepada bayinya minimal sampai bayi berumur 4 bulan karena jika menggunakan ketentuan pemberian ASI eksklusif sampai 6 bulan sesuai rekomendasi dari UNICEF, maka akan didapatkan angka yang jauh lebih kecil dari yang diharapkan. Hasil penelitian menujukkan hanya $60 \%$ dari responden memberikan ASI eksklusif kepada bayinya minimal 4 bulan. Hasil ini belum sesuai dengan komitmen seperti yang tercantum dalam UU RI No. 25 tahun 2000 tentang Program Pembangunan Nasional (Propenas) tahun 2000-2004 yang menyebutkan bahwa tingkat pencapaian pemberian ASI eksklusif ibu kepada bayinya harus mencapai target $80 \%{ }^{8}$ Hasil penelitian menunjukkan bahwa meskipun sebagian besar responden (78\%) mempunyai pengetahuan tentang ASI eksklusif baik, namun masih banyak responden yang belum memberikan ASI eksklusif kepada bayinya yaitu sebesar $40 \%$. 
salah satu alasan yang menyebabkan ibu tidak memberikan ASi eksklusif adalah karena ibu bekerja, terutama ibu dengan cuti hamil 3 bulan. Namun, hasil yang ditunjukkan dalam penelitian ini, responden yang sebagian besar adalah ibu rumah tangga atau tidak bekerja, pencapaian pemberian ASI eksklusif kepada bayi belum mencapai angka yang diharapkan. ${ }^{6}$

Hal ini disebabkan ada faktor-faktor lain yang mempengaruhi pemberian ASI eksklusif. Faktor-faktor tersebut diantaranya: faktor psikologi, takut kehilangan daya tarik sebagai seorang wanita; faktor fisik, ibu sakit atau putting susu masuk ke dalam sehingga bayi tidak mau menyusu; gencarnya promosi susu formula; dan faktor kurangnya peran petugas kesehatan dalam mempromosikan ASI eksklusif menyebabkan masyarakat kurang mendapat informasi dan dukungan tentang manfaat pemberian ASI eksklusif. ${ }^{9}$

Bekerja bukan alasan untuk menghentikan pemberian ASI eksklusif sampai 6 bulan, meskipun cuti hamil hanya 3 bulan. Dengan pengetahuan yang benar tentang menyusui, perlengkapan memerah ASI, dan dukungan lingkungan kerja, seorang ibu yang bekerja dapat tetap memberikan ASI secara eksklusif. ${ }^{6}$

\section{SIMPULAN DAN SARAN}

\section{a. Simpulan}

Responden yang mempunyai tingkat pengetahuan tentang ASI eksklusif baik sebanyak $78 \%$, tingkat pengetahuan tentang ASI eksklusif sedang sebanyak $19 \%$, dan tingkat pengetahuan tentang ASI eksklusif kurang sebanyak $3 \%$. Pemberian ASI eksklusif di Puskesmas Cilacap Tengah sebanyak $60 \%$ sedangkan $40 \%$ tidak memberikan ASI eksklusif. Berdasarkan hasil penelitian bahwa tidak selalu orang yang memiliki pengetahuan dan pemahaman atas sesuatu hal akan menunjukkan perilaku yang serupa dengan apa yang diketahuinya. Hal tersebut menunjukkan bahwa ibu yang mempunyai pengetahuan tentang ASI eksklusif baik tidak selalu memberikan ASI eksklusif kepada bayinya karena masih banyak faktor-faktor lain yang mempengaruhi pemberian ASI eksklusif.

\section{b. Saran}

Perlu dilakukan penelitian yang lebih mendalam mengenai pemberian ASI eksklusif dengan pendekatan lebih detail secara kualitatif selain menggunakan pendekatan kuantitatif. Pengambilan data tidak hanya menggunakan kuesioner tetapi juga dengan observasi langsung serta dengan menambah variabel penelitian mengingat tidak hanya faktor pengetahuan saja yang mempengaruhi pemberian ASI eksklusif.

\section{DAFTAR PUSTAKA}

1. Supriyadi, R.W. at all. Kiat sukses menyusui. Jakarta: Aspirasi Pemuda. (2002).

2. Anonim. Strategi Nasional PP-ASI. http://www.gizi.net/kebijakangizi/html.29 Juli 2003. 2003

3. Emilia, S. \& Hamzah. Upaya menurunkan angka kematian dan angka kesakitan balita. Di dalam : Kardjati, Kusin \& Anna, A., editors. Aspek kesehatan dan gizi balita. Jakarta: Yayasan Obor Indonesia.1985

4. Notoatmodjo, S. Pengantar pendidikan kesehatan dan ilmu perilaku kesehatan. Yogyakarta: Andi Offset. 2003

5. . IImu kesehatan masyarakat prinsip-prinsip dasar. Jakarta: Rineka Cipta.1997

6. Roesli, U. Mengenal ASI eksklusif. Jakarta: Trubus Agriwidya.2000

7. Indrawijaya, A. Perilaku organisasi. Bandung: Sinar Baru Algersindo.2000 
8. Anwar, S.A. Hak asasi bayi dan pekan ASI sedunia. http://www.suaramerdeka.com.29 Juli 2003.2003

9. Soetjiningsih. ASI petunjuk untuk tenaga kesehatan. Jakarta: EGC.1997 